\title{
Restorative management of dental enamel defects in the primary dentition
}

\author{
Hani Nazzal ${ }^{1,2}$ - Monty S. Duggal ${ }^{3}$
}

Received: 8 August 2018 / Accepted: 19 October 2018 / Published online: 23 November 2018

(c) The Author(s) 2018

\begin{abstract}
Management of primary teeth with enamel defects in the young child can be challenging. Many restorative techniques for the management of such teeth are available; however, factors such as patient's medical history, compliance, needs, pain experience, and expectations should be considered. Furthermore, management of such teeth might require short and long management treatment plans depending on the extent and severity of such defects.
\end{abstract}

Keyword Enamel defects · Primary teeth $\cdot$ Restorative management

\section{Quick reference/description}

Enamel defects in the primary dentition, as a result of different genetic and environmental conditions, can result in pain, esthetic concerns, and tooth surface loss, therefore, affecting the child's quality of life. Management of such conditions is affected by several factors such as the type of teeth affected, extent of defects, tooth surface loss, prognosis and associated symptoms.

The following chapter summarizes different treatment modalities, in managing primary teeth with enamel defects, highlighting the indications, advantages, and disadvantages for each treatment modality.

Hani Nazzal

haninazzal@hotmail.com

1 Paediatric Dentistry, Hamad Medical Corporation, Doha, Qatar

2 School of Dentistry, University of Leeds, Leeds, UK

3 Paediatric Dentistry Department, National University of Singapore, Singapore,

Republic of Singapore 


\section{Overview}

It is prudent to highlight that caries prevention is essential in the management of all patients especially those with developmental defects of enamel. Following are different treatment options for restorative management of dental enamel defects in the primary dentition:

\begin{tabular}{|c|c|c|c|}
\hline Treatment & Indications & Advantages & Disadvantages \\
\hline \multicolumn{4}{|c|}{ I. Interim restorations } \\
\hline Glass ionomer & $\begin{array}{l}\text { Pain } \\
\text { Sensitivity }\end{array}$ & $\begin{array}{l}\text { Short-term alleviation } \\
\text { of pain and sensitivity } \\
\text { Short-term management } \\
\text { of tooth surface loss } \\
\text { Fluoride release and } \\
\text { ease of application }\end{array}$ & $\begin{array}{l}\text { Not a definitive restora- } \\
\text { tive treatment }\end{array}$ \\
\hline \multicolumn{4}{|c|}{$\begin{array}{l}\text { II. Longer term restora- } \\
\text { tions of posterior teeth }\end{array}$} \\
\hline $\begin{array}{l}\text { Composite resin } \\
\text { restorations }\end{array}$ & $\begin{array}{l}\text { Defect is demarcated } \\
\text { to a defined area, } \\
\text { not more than two } \\
\text { surfaces } \\
\text { No significant sensitiv- } \\
\text { ity } \\
\text { Supragingival margins } \\
\text { of the defect }\end{array}$ & $\begin{array}{l}\text { Tooth coloured, good } \\
\text { compressive strength }\end{array}$ & $\begin{array}{l}\text { Hypomineralised enamel } \\
\text { can potentially reduce } \\
\text { the strength and integ- } \\
\text { rity bond of enamel to } \\
\text { composite resin } \\
\text { Further tooth structure } \\
\text { loss leading to defective } \\
\text { restorations }\end{array}$ \\
\hline $\begin{array}{l}\text { Preformed metal } \\
\text { crowns }\end{array}$ & $\begin{array}{l}\text { The defect involves } \\
\text { multiple surfaces } \\
\text { There is significant } \\
\text { sensitivity } \\
\text { Margins of defects are } \\
\text { subgingival } \\
\text { There is involvement } \\
\text { of the cusp tips in } \\
\text { posterior teeth } \\
\text { Enamel is prone to } \\
\text { "chipping," especially } \\
\text { in some cases of } \\
\text { hypocalcified Amelo- } \\
\text { genesis imperfecta } \\
\text { (AI) } \\
\text { Uncooperative child } \\
\text { requiring treat- } \\
\text { ment under general } \\
\text { anaesthesia as such } \\
\text { child would not allow } \\
\text { further treatment in } \\
\text { the future }\end{array}$ & $\begin{array}{l}\text { Good occlusal support } \\
\text { provided by stainless } \\
\text { steel crowns } \\
\text { Requires minimal tooth } \\
\text { preparation less bulky } \\
\text { Failure rate is much less } \\
\text { than other restorative } \\
\text { materials } \\
\text { Moisture control is less } \\
\text { critical than when } \\
\text { restoring with other } \\
\text { materials } \\
\text { Placement is less time } \\
\text { consuming than resin } \\
\text { restorations } \\
\text { Are more cost effective } \\
\text { as shown by the out- } \\
\text { comes over time }\end{array}$ & $\begin{array}{l}\text { Low esthetic results } \\
\text { due to full tooth silver } \\
\text { colour }\end{array}$ \\
\hline
\end{tabular}




\begin{tabular}{|c|c|c|c|}
\hline Treatment & Indications & Advantages & Disadvantages \\
\hline $\begin{array}{l}\text { Pre-veneered metal } \\
\text { crowns and white } \\
\text { crowns }\end{array}$ & $\begin{array}{l}\text { Large lesions involving } \\
\text { multiple surfaces } \\
\text { Subgingival lesions } \\
\text { Sensitivity }\end{array}$ & Good esthetic results & $\begin{array}{l}\text { Require more extensive } \\
\text { crown preparation } \\
\text { Higher cost } \\
\text { Chipping can occur in } \\
\text { the pre-veneered metal } \\
\text { crowns } \\
\text { Subgingival preparation } \\
\text { in the zirconia crowns } \\
\text { with more tooth struc- } \\
\text { ture loss } \\
\text { Possibility of pulp expo- } \\
\text { sures compromising } \\
\text { pulpal health } \\
\text { No available high-quality } \\
\text { long-term success } \\
\text { studies }\end{array}$ \\
\hline \multicolumn{4}{|l|}{$\begin{array}{l}\text { III. Longer term restora- } \\
\text { tions of anterior teeth }\end{array}$} \\
\hline $\begin{array}{l}\text { Composite restora- } \\
\text { tions }\end{array}$ & $\begin{array}{l}\text { Demarcated lesions } \\
\text { Large lesions involving } \\
\text { multiple surfaces } \\
\text { Sensitivity }\end{array}$ & Good esthetic results & $\begin{array}{l}\text { Require tooth surface } \\
\text { removal }\end{array}$ \\
\hline Composite veneers & $\begin{array}{l}\text { Diffuse lesions } \\
\text { Large lesions involving } \\
\text { multiple surfaces } \\
\text { Sensitivity }\end{array}$ & Good esthetic results & $\begin{array}{l}\text { Bulkier teeth } \\
\text { Risk of composite chip- } \\
\text { ping }\end{array}$ \\
\hline $\begin{array}{l}\text { Full coverage white } \\
\text { crowns }\end{array}$ & $\begin{array}{l}\text { Diffuse lesions } \\
\text { Large lesions involving } \\
\text { multiple surfaces } \\
\text { Subgingival lesions } \\
\text { Sensitivity }\end{array}$ & Good esthetic results & $\begin{array}{l}\text { Require more extensive } \\
\text { crown preparation } \\
\text { Higher cost } \\
\text { Chipping can occur in } \\
\text { the pre-veneered metal } \\
\text { crowns } \\
\text { Subgingival preparation } \\
\text { in the zirconia crowns } \\
\text { with more tooth struc- } \\
\text { ture loss } \\
\text { Possibility of pulp expo- } \\
\text { sures compromising } \\
\text { pulpal health } \\
\text { No available high-quality } \\
\text { long-term success } \\
\text { studies }\end{array}$ \\
\hline $\begin{array}{l}\text { IV. Extraction of } \\
\text { primary teeth with } \\
\text { DDE (developmental } \\
\text { defects of enamel) }\end{array}$ & $\begin{array}{l}\text { Extensive tooth surface } \\
\text { loss resulting in unre- } \\
\text { storable teeth } \\
\text { Pulpal involvement- } \\
\text { irreversible pulpitis/ } \\
\text { necrotic pulps }\end{array}$ & & $\begin{array}{l}\text { Space required for devel- } \\
\text { oping dentition may be } \\
\text { affected }\end{array}$ \\
\hline
\end{tabular}



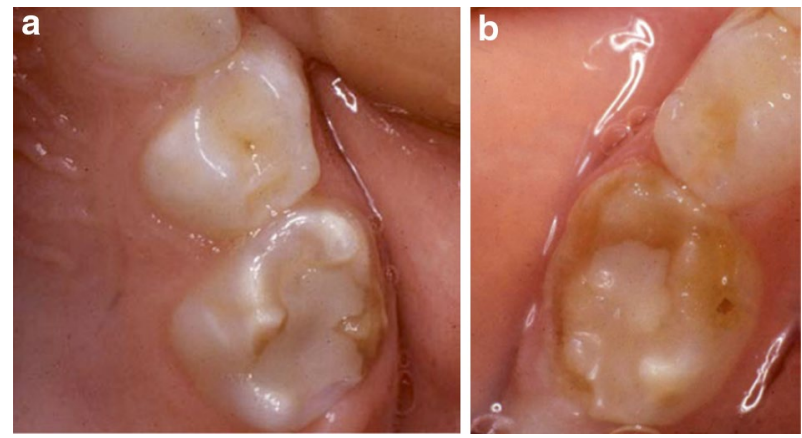

Fig. 1 a, b Example of the use of a glass ionomer cement used for interim protection on hypomineralised second primary molars (Courtesy of Nicky Kilpatrick)

\section{Materials/instruments}

- Resin-modified glass ionomer (Fuji VII/triage, GC Corporation, Singapore)*

- Compomer materials (Esthet.X, Dentsply, Surrey, UK)*

- Preformed metal crowns (3M ${ }^{\mathrm{TM}}$ ESPE ${ }^{\mathrm{TM}}$ Stainless Steel Primary Molar Crowns, USA $*^{* 1}$

- Pre-veneered metal crowns and white crowns such as NuSmile signature, preveneered kinder crowns ${ }^{\circledR}$, and Zirconia crowns (NuSmile zirconia and Zirconia anterior kinder crowns ${ }^{\circledR}$ ).

\section{Procedure}

There are two main types of enamel defects:

Hypoplastic: caused by incomplete or defective formation of the organic enamel matrix by ameloblasts during tooth formation (secretory stage) resulting in thinner but normally mineralized enamel.

Hypomineralized enamel: occurs due to a failure in enamel matrix mineralization.

The decision to provide restorative management of enamel defects in primary teeth depends on several factors:

- Types of enamel defect.

- Extent and severity of the defects,

- Associated symptoms,

- Esthetics with possible psychological effects on the child,

- Patient cooperation and the method of treatment.

$1 *$ Other products are available in the market and could be used. 


\section{Interim restorations}

An interim therapeutic restoration immediately alleviates pain and sensitivity. The provision of these interim restorations also allows the clinician to establish rapport with the child and assist in behavior management.

Materials such as resin-modified glass ionomer can be useful as these materials incorporate appropriate bonding for both enamel and any exposed dentin (Fig. 1). Glass ionomer could also be used for interim restoration.

\section{Longer term restorations of molar teeth}

\section{Composite resin restorations}

Composite restorations are indicated in cases where:

- Defect is demarcated to a defined area, not more than two surfaces

- Cusp tips are not involved

- No significant sensitivity

- Supragingival margins of the defect.

Composite resin restorations require good isolation, preferably using rubber dam. Pretreatment with 5\% sodium hypochlorite could improve composite retention through deproteination of hypomineralised enamel. Removal of excess enamel
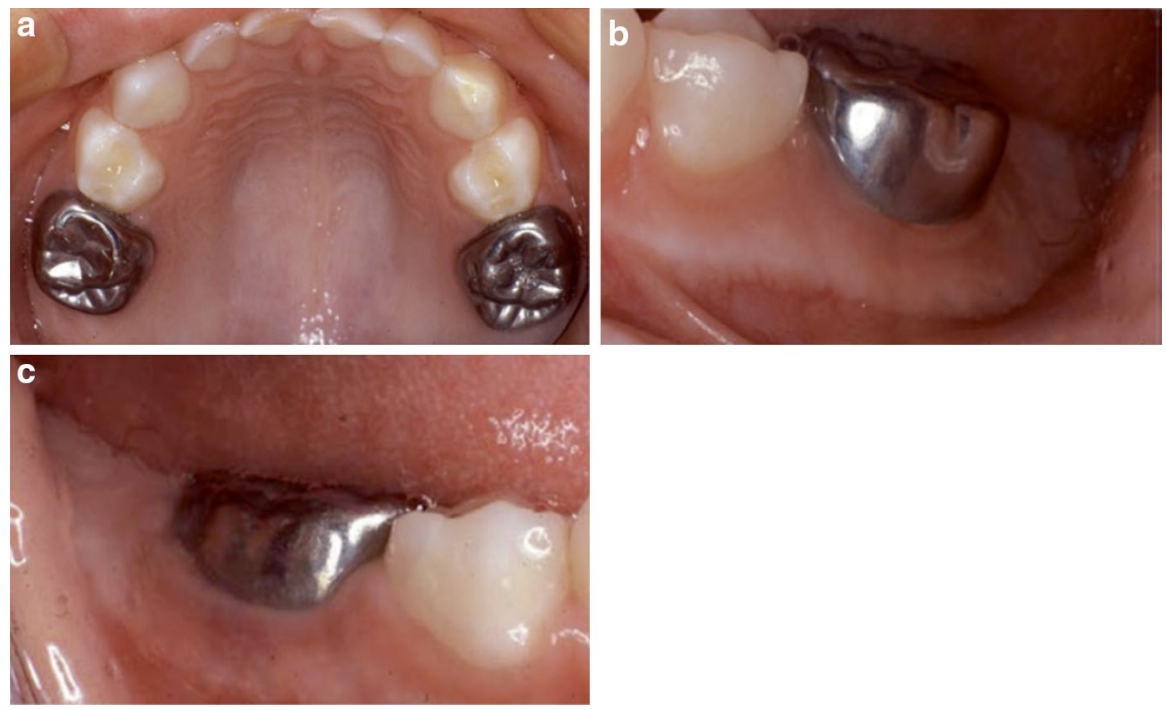

Fig. 2 Post-placement of stainless steel crowns on second primary molars using the Hall technique (Courtesy of Nicky Kilpatrick) 
protein could make the enamel crystals more accessible to the etching solution, therefore, improving retention.

\section{Preformed metal crowns}

The use of preformed metal crowns (stainless steel crowns) is a well-recognized option for the treatment of carious primary molars, and has an important role in the management of DDE-affected primary molars.

Following are the indications of preformed crowns:

- The defect involves multiple surfaces

- There is significant sensitivity

- Margins of defects are subgingival

- There is involvement of the cusp tips in posterior teeth

- Enamel is prone to "chipping," especially in some cases of AI

- Treatment has to be carried out under general anesthesia and the child is unlikely to manage restorative care in the immediate future.

A technique, known as the "Hall Technique", has been described mainly for the uncooperative child in which stainless steel crowns are placed with no preparation (Fig. 2). This technique is very useful in the management of primary teeth with DDE.

\section{Long term restorations of anterior teeth}

Anterior teeth can be appropriately restored by composite restorations including the use of strip crowns when multiple surfaces are involved (Fig. 3).

The steps for placing strip crowns involve:

- Removal of approximately 1-2 mm of enamel from all the surfaces of the crown.

- The enamel is etched and prepared for bonding according to the manufacturer's instructions and the crown is filled with composite, placed on the tooth, with excess removed from the margins and the composite cured.

- Once the strip crown has been removed, the restoration is finished in the usual manner.

Fig. 3 Anterior primary incisors with zirconia crowns (Courtesy of Bernadette Drummond)

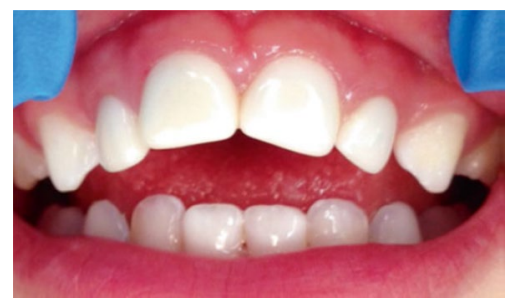


The use of full coverage white crowns, such as zirconia crowns, for restoration of anterior teeth is mainly indicated when more extensive tooth surface loss is evident with subgingival finish lines. The use of this technique is growing among clinicians although more extensive tooth surface preparation is needed with risk of pulp exposure as such crowns offer better esthetic results and full tooth coverage (Fig. 3).

\section{Extraction of primary teeth with DDE}

Severely affected teeth with extensive tooth surface loss may require extraction. This should be done with evaluation of the space requirements in the developing dentition.

Preventive and restorative approaches should be preferred over extraction where possible.

\section{Pitfalls and complications}

- Interim restorations are not a definitive restorative treatment.

- Hypomineralised enamel can potentially reduce the strength and integrity of composite resin bond to enamel.

- Pre-veneered and white crowns require more extensive crown preparation than preformed metal crowns.

- Higher cost of treatment in more generalized cases.

- Chipping can occur in the pre-veneered metal crowns.

Open Access This article is distributed under the terms of the Creative Commons Attribution 4.0 International License (http://creativecommons.org/licenses/by/4.0/), which permits unrestricted use, distribution, and reproduction in any medium, provided you give appropriate credit to the original author(s) and the source, provide a link to the Creative Commons license, and indicate if changes were made.

\section{Further reading}

1. Duggal MS, Nazzal H (2015) Restorative management of dental enamel defects in the primary dentition. In: Drummond B, Kilpatrick N (eds) Planning and care for children and adolescents with dental enamel defects: etiology, research and contemporary management. Springer, Berlin, pp 123-137

2. Welbury R, Gillgrass T (2012) Craniofacial growth and development, chapter 1. In: Welbury R, Duggal M, Hosey M (eds) Paediatric dentistry, 4th edn. Oxford University Press, Oxford, pp 12-13

3. McDonald S, Arkutu N, Malik K, Gadhia K, McKaig S (2012) Managing the paediatric patient with amelogenesis imperfecta. Br Dent J 212(9):425-428 